\title{
Measuring the impact of CLIL on language skills: a CEFR- based approach for Higher Education
}

\author{
Antonio José Jiménez-Muñoz \\ jimenezantonio@uniovi.es \\ Universidad de Oviedo, Spain
}

\begin{abstract}
Advocates of CLIL (Content and Language Integrated Learning) have extolled the virtues of this approach to fostering both content and language alike. However, the generalised and varied implementation of EMI (English as a Medium of Instruction) in universities worldwide has led many lecturers to question these claims. This paper presents a CEFR (Common European Framework)-based model for measuring the impact of EMI at the tertiary level, the aim being to provide further evidence of the progress made in language-learning in modules taught in a foreign language. Using questionnaires based on the revised and refined CEFR descriptors from EAQUALS (Evaluation and Accreditation of Quality in Language Services), students answer an initial self-assessment survey about their background and language skills, which is controlled by a final questionnaire targeting their perceived progress throughout their instruction. Designed from the ground up with the CEFR as a backdrop, this method can be easily tallied with objective assessment to uncover data about students' linguistic performance in CLIL contexts.
\end{abstract}

Keywords: CLIL, CEFR, EMI, educational research, plurilingualism

\section{CLIL AS A CONTESTED APPROACH}

Most universities around the globe now offer full or partial degrees taught through a foreign language. English has long been the language of science, but these degrees have made English "the language of higher education in Europe" (Coleman 2006: 1). Part programmatic development, part explicit competition in a wider tertiary environment, English has become the de-facto language for academic discourse and those refusing to provide English-taught modules endanger their global scientific visibility (Alexander 2006). Particularly in Europe, there is a strong consensus on the methodological approach to be used when a content module or degree is taught through a language other than the students' mother tongue (often in English as the Medium of Instruction, or EMI). Content and Language Integrated Learning (CLIL) "is part of mainstream school education in the great majority of countries at primary and secondary levels" (Eurydice 
2006: 13) and, more recently, it has also become a major move towards multilingualism at the tertiary level (Fortanet-Gómez 2013). Unlike immersion programmes, multilingualism and CLIL assume that the role of language for the participants need not be transparent for either lecturer or student (Lagasabaster and Sierra 2010) and devise interventions to foster linguistic skills alongside content.

Rather than being a strict method, CLIL is "essentially methodological" (Marsh 2008: 244). Its theorists claim it fosters a flexible, inclusive approach which can be applied through many specific methodologies, since both content and language are integrated. Its advocates stress that by "integrating language and subject teaching, various forms of educational success can be achieved where classrooms comprise learners with diverse levels of linguistic competence" (Marsh 2006: 3). They believe it creates an "innovative fusion of non-language subject with and through a foreign language" (Coyle, Hood and Marsh 2010: 1) and, as it focuses mainly on explaining meaning and not language per se, it allows for "implicit and incidental learning" in "naturalistic situations" (Marsh 2002: 72). CLIL reportedly enables one "to learn as you use and use as you learn" (Marsh 2002: 66) rather than learning language on its own or as separate from content.

While the introduction of CLIL/EMI opens a window for the revision of instructional strategies in many disciplines, a considerable number of participants have observed the problems it adds to their programmes of study. Language level is often at the core of this criticism; content lecturers have complained about the lack of sophistication in their students' use of English (Erling and Hilgendorf 2006: 284) and questioned their own abilities to tackle linguistic issues (Airey 2013: 64), particularly in the case of nonnative English (Coyle 2008: 105-106). The seemingly implicit need for the "watering down and simplification of content to make it comprehensible" (Costa and Coleman 2010: 13) questions the quality of learning in EMI contexts. Some have thus called for the "limiting effect" of a foreign language as a medium of instruction on students' final performance to be accepted as something unavoidable (Clegg 2001: 210).

Prima facie, CLIL as theory and its implementation as practice seem to be at odds. Opponents, however, often overlook the fact that provisions made for vital structural readjustments affecting budget, staff development and educational design (Mellion 2006) may not always have been well designed (Airey 2011: 43-45). There is clearly a 
need for more development programmes, and advances in teacher-training (Marsh, Mehisto, Wolff and Frigols-Martin 2012) may help design better programmes that target the specific skills needed to teach through a second language (Ball and Lindsay 2013). Lecturers nevertheless attempt to overcome these linguistic hurdles with a number of mediations, techniques and approaches, but the success of these actions is often left unexplored, analysed subjectively or tightly linked to results. A closer assessment of both the effectiveness of those practices and their connection to the expected learning outcomes is essential to guarantee quality. For the learner, it is not a case of either-or: students need both content and language for future studies and employment (Rienties, Brouwer and Lygo-Baker 2013). Until conclusive proof is found, the controversy over the usefulness of CLIL and EMI to promote excellence in both content and language learning will continue. Our study seeks to begin to address the lack of empirical evidence by establishing an evaluation framework that could be readily applicable to various CLIL implementations in order to provide proof towards their effect on the English of learners.

\section{THE NEED FOR EVIDENCE-BASED RESEARCH}

There is a strong need to provide evidence for the hypotheses surrounding CLIL. The hopeful advantage of teaching "two for the price of one" and the "added value of CLIL" both need to be supported (Bonnet 2012: 66) to avoid the "risk of becoming a 'buzz word' without evidence-based research" (Hunter and Parchoma 2012). Unless this research is carried out to assess the quality of language-learning under CLIL programmes, they run the risk of becoming undervalued despite their obvious merits. Most criticism is focused on the idea that A2-B1 students fresh from high school will find it impossible to cope with the linguistic demands of academic tasks; as a student progresses towards C1-level, this perception of English as limiting students' academic performance becomes gradually unsustainable. However, several reasonable questions remain: how much does a student progress in his or her language proficiency with no specific language instruction? How successful are particular instruction tactics to teach the language and motivate students towards linguistic subtleties? How aware of their linguistic progress are students and how do they qualify it? 
There has been comparatively little hands-on research assessing the effectiveness of CLIL implementations, and most of what has been conducted has been mainly restricted to primary and secondary education (Thomas and Collier 2002; Barnett, Yarosz, Thomas, Jung and Blanco 2007; Cobb, Vega and Kronauge 2009; Lindholm-Leary 2011). Some studies, such as Kirkgöz (2005, 2009), Vizconde (2006) and Londo (2012), have centred upon student motivation and attitudes towards the use of EMI in higher education, while others have linked particular skills to academic results (Morrison, Merrick, Higgs and Le Métais 2005; Rienties, Beausaert, Grohnert, Niemantsverdriet and Kommers 2012). However, there is very little empirical research on students' actual performance which is data-driven (Llinares and Whittaker 2010). Gradually, studies focused on particular skills (Ruiz de Zarobe 2010, Navés 2011) and the effect of language level on learning content (Aguilar and Muñoz 2013) are appearing, but more solid and standardised evidence is needed for the language learning taking place under CLIL/EMI conditions, particularly in higher education contexts.

\section{A CEFR-BASED RESEARCH METHOD}

The multiplicity of different linguistic skills displayed by students in class requires conflating these skills into a framework which makes students' progress in reading, writing, listening and speaking understandable, referable and translatable. With its detailed use of descriptors, we have a perfect backdrop in the CEFR for the interpretation of particular learner skills. Thus, thinking inversely, those tools which aim to assess that linguistic performance would benefit from observing the CEFR from the ground up, rather than having their outcomes transferred to CEFR descriptors and levels. Our approach designs a framework which grades student abilities and interprets them into CEFR-coded language, which is in turn easier for linguists to demonstrate against students' actual oral and written performance. It also helps when it comes to tracking learner performance over time, so that a student would progress or regress among different levels in that particular skill during their period of EMI instruction. Consequently, it may prove a valuable tool to show both qualitative and quantitative evidence for the actual linguistic learning taking place in CLIL/EMI programmes. 
The aim of our study, then, is to offer an initial but solid framework for such evaluation based upon the CEFR levels and descriptors as revised and refined by EAQUALS (Evaluation and Accreditation of Quality in Language Services). These expanded, new levels and descriptors are more readily usable by university students as they are more varied and their wording is less technical than the original CEFR descriptors developed in the 1990s. The new EAQUALS design also helps identify a total of eleven levels instead of the original six, which adds granularity and refinement, thereby making these descriptors particularly useful for shorter periods of reduced direct instruction, such as university semesters.

\section{III.1. Design phase}

The implementation of our framework has three major stages: design, data-collection and evaluation. In the design phase, content lecturers allocate CEFR-compliant skills and sub-skills for students to perform, as specified in the module syllabus, and their attached tasks. These particular skills are then individually mapped onto their respective CEFR level, which offers a detailed multi-level grid of the expected level from students. Doing so has several inherent diagnostic advantages, such as detecting potential problems, designing strategies to promote excellence or setting an egress CEFR level, as well as realising the linguistic complexity of those academic tasks set by lecturers. Often overlooked in L1 contexts, this effect in module design might hinder students' academic performance on purely linguistic grounds. These sub-skills are the major part of a questionnaire reflecting actual student ability as per CEFR levels both in each grouped skill and globally. Our survey adds more details about students' background and profile to enable subject modelling and prototyping.

\section{III.2. Data collection}

First, students must complete an initial questionnaire (at the beginning of the semester, module or course) detailing their attitude towards studies, intrinsic motivation and selfperception of their English-language skills. The language part of the questionnaire is standardised according to CEFR/EAQUALS descriptors (see references below), but students are not given any indication about the level each descriptor belongs to. They 
are required to evaluate their confidence in doing a number of linguistic tasks. In this way, students are in fact grading themselves in the skills and sub-skills identified as being required for their university core modules and tasks. Additionally, it allows quantitative fine-graining, in five degrees, of their confidence in their performance in each skill, and fallibility control by means of items of the same skill/level in the same questionnaire. A second questionnaire is presented towards the end of the research period. When data has been compiled and analysed, this method allows student perceptions to be verified through an analysis of the oral or written work they have produced in their modules, which in turn enables language to be prototyped and linked to students' academic achievement.

\section{III.2.1 Initial survey}

Please note that this survey is a tailored questionnaire, specifically designed for firstyear students in an EMI Economics degree programme at a Spanish university and, as such, it could serve as a proof-of-concept, to be expanded and adapted to other contexts. Students have a minimum A2 level of English in all four skills, although their background and language abilities vary greatly. The survey is computerised, nominal and all items are compulsory. Items 1-3 are demographic. Items 4-15 enquire about the English-related educational background of the student to enable modelling/prototyping. Items 16-19 respond to those skills needed in students' particular degree programmes and in this case vary from $\mathrm{B} 1$ to $\mathrm{C} 1$ levels, since a full $\mathrm{A} 1-\mathrm{C} 2$ range is possible but unmanageable. The full CEFR range is kept, however, for a more general evaluation of control items 20-27. CEFR level references, in square brackets, are stated for the purposes of this paper, but are not present in the actual student survey.

Table 1. English Level Self-Assessment: Initial Survey

\begin{tabular}{|c|c|}
\hline 1. Please state your sex. & $\begin{array}{ll}- & \text { Male } \\
- & \text { Female } \\
\end{array}$ \\
\hline 2. Which year were you born? & (open numeric answer) \\
\hline 3. Which is your first language? & $\begin{array}{ll}\text { - } & \text { Spanish } \\
\text { - } & \text { French } \\
\text { - } & \text { Italian }\end{array}$ \\
\hline
\end{tabular}




\begin{tabular}{|c|c|}
\hline & $\begin{array}{ll}\text { - } & \text { German } \\
\text { - } & \text { An Asian language } \\
\text { - } & \text { Another Romance language } \\
\text { - } & \text { Another Germanic language } \\
\text { - } & \text { A Slavic language } \\
\text { - } & \text { Other }\end{array}$ \\
\hline $\begin{array}{l}\text { 4. Please state whether you can use } \\
\text { other languages and, if so, how } \\
\text { well, using } 1 \text { (= not spoken) to } 5 \\
\text { (fluent). }\end{array}$ & $\begin{array}{ll}\text { - } & \text { Spanish }(1-5) \\
\text { - } & \text { French }(1-5) \\
\text { - } & \text { Italian }(1-5) \\
\text { - } & \text { German }(1-5) \\
\text { - } & \text { An Asian language }(1-5) \\
\text { - } & \text { Another Romance language }(1-5) \\
\text { - } & \text { A Slavic language }(1-5) \\
\text { - } & \text { Other - please specify }(1-5)\end{array}$ \\
\hline $\begin{array}{l}\text { 5. How many years have you been } \\
\text { learning English? }\end{array}$ & (open numeric answer) \\
\hline $\begin{array}{l}\text { 6. Which of these aspects do you } \\
\text { find particularly difficult about } \\
\text { learning English? (You can select } \\
\text { more than one) }\end{array}$ & $\begin{array}{ll}\text { - } & \text { Grammar structures } \\
\text { - } & \text { Vocabulary } \\
\text { - } & \text { Pronunciation } \\
\text { - } & \text { Understanding what I read } \\
\text { - } & \text { Understanding native speakers } \\
\text { - } & \text { Understanding other foreigners when they speak English } \\
\text { - } & \text { Writing long, formal texts } \\
\text { - } & \text { Writing short, informal texts } \\
\text { - } & \text { Speaking English with native speakers } \\
\text { - } & \text { Speaking English with other foreigners } \\
\end{array}$ \\
\hline $\begin{array}{l}\text { 7. Which of these aspects do you } \\
\text { find easier about learning English? } \\
\text { (You can select more than one) }\end{array}$ & $\begin{array}{ll}\text { - } & \text { Grammar structures } \\
\text { - } & \text { Vocabulary } \\
\text { - } & \text { Understanding what I read } \\
\text { - } & \text { Understanding native speakers } \\
\text { - } & \text { Understanding other foreigners when they speak English } \\
\text { - } & \text { Writing long, formal texts } \\
\text { - } & \text { Writing short, informal texts } \\
\text { - } & \text { Speaking English with native speakers } \\
\text { - } & \text { Speaking English with other foreigners }\end{array}$ \\
\hline $\begin{array}{l}\text { 8. Which of these do you regularly } \\
\text { do in English, if any? (You can } \\
\text { select more than one item) }\end{array}$ & $\begin{array}{ll}\text { - } & \text { Listening to music } \\
\text { - } & \text { Reading books or magazines } \\
\text { - } & \text { Reading websites } \\
\text { - } & \text { Speaking to other people } \\
\text { - } & \text { Writing on the phone/webcam } \\
\text { - } & \text { Using social networks, text-based chat or forums } \\
\text { - } & \text { Watching online videos, films or TV programmes } \\
\text { - } & \text { Other - please specify }\end{array}$ \\
\hline $\begin{array}{l}\text { 9. Have you ever been to an } \\
\text { English-speaking country, lived, } \\
\text { studied or worked with people } \\
\text { whose first language was English, } \\
\text { so you had to use English for } \\
\text { communication? } \\
\text { Please state the total amount of } \\
\text { time these experiences lasted for. }\end{array}$ & $\begin{array}{ll} & \text { Never } \\
\text { - } & 1 \text { month } \\
\text { - } & 1-3 \text { months } \\
\text { - } & 4-6 \text { months } \\
\text { - } & 6-12 \text { months } \\
\text { - } & \text { More than } 1 \text { year } \\
\text { - } & \text { More than } 2 \text { years } \\
\text { - } & \text { More than } 3 \text { years }\end{array}$ \\
\hline
\end{tabular}




\begin{tabular}{|c|c|}
\hline & - 4 years or more \\
\hline $\begin{array}{l}\text { 10. Please state your general } \\
\text { attitude towards these points, using } \\
1 \text { (very negative) to } 5 \text { (very } \\
\text { positive). }\end{array}$ & $\begin{array}{ll}\text { - } & \text { English language (1-5) } \\
\text { - } & \text { English lessons (1-5) } \\
\text { - } & \text { English teachers (1-5) } \\
\text { - } & \text { British or American culture (1-5) } \\
\text { - } & \text { The culture of other English-speaking countries (1-5) } \\
\text { - } & \text { British or American native speakers }(1-5) \\
\text { - } & \text { Speakers from other English-speaking countries (1-5) } \\
\text { - } & \text { Speaking in English with foreigners (1-5) }\end{array}$ \\
\hline $\begin{array}{l}\text { 11. How would you describe your } \\
\text { general level of English? }\end{array}$ & $\begin{array}{ll}\text { - } & \text { Basic or Elementary } \\
\text { - } & \text { Pre-intermediate } \\
\text { - } & \text { Intermediate } \\
\text { - } & \text { Upper-intermediate } \\
\text { - } & \text { Advanced } \\
\text { - } & \text { Proficient / Bilingual } \\
\end{array}$ \\
\hline $\begin{array}{l}\text { 12. What are your motivations for } \\
\text { studying/improving your English? } \\
\text { (You can select more than one) }\end{array}$ & $\begin{array}{l}\text { - } \text { Travelling around the world } \\
\text { - } \text { Meeting people from different countries } \\
\text { - } \text { Having more opportunities in the future } \\
\text { - } \quad \text { Finding a job in the future } \\
\text { - Using the language as a tool to work in my country } \\
\text { - Using the language as a tool to work abroad } \\
\text { - Selling goods to other countries } \\
\text { - } \quad \text { Being socially respected } \\
\text { - Other - please specify }\end{array}$ \\
\hline $\begin{array}{l}\text { 13. What was your approximate } \\
\text { university access test grade in the } \\
\text { English paper? Please use a comma } \\
\text { for decimals. Example: } 8,2\end{array}$ & (open numeric answer) \\
\hline $\begin{array}{l}\text { 14. Have you taken any extra } \\
\text { English courses, apart from those at } \\
\text { school? }\end{array}$ & $\begin{array}{ll} & \text { Never } \\
- & \text { About one year } \\
\text { - } & \text { About 2-3 years } \\
\text { - } & \text { About 4-5 years } \\
\text { - } & \text { About 6-7 years } \\
\text { - } & \text { More than 7 years } \\
\end{array}$ \\
\hline $\begin{array}{l}\text { 15. Which is the highest English } \\
\text { certificate you have obtained? }\end{array}$ & $\begin{array}{l}\text { - } \quad \text { No certificate, just high-school / Official Language School } \\
\text { Basic level / Cambridge KET with merit or PET / Trinity } 3 \text { or } \\
4 \text { (CEFR A2, or similar certificate) } \\
\text { Official Language School Intermediate level / Cambridge } \\
\text { PET with merit or FCE grade D / Trinity } 4 \text { or } 5 \text { (CEFR B1, or } \\
\text { similar certificate) } \\
\text { Official Language School Advanced level / Cambridge PET } \\
\text { with distinction, FCE grade B or C, CAE grade D / Trinity 6, } \\
7 \text { or } 8 \text { (CEFR B2, or similar certificate) } \\
\text { Official Language School C1 / Cambridge FCE grade A, } \\
\text { CAE grade B or C, CPE grade D / Trinity } 10 \text { or } 11 \text { (CEFR } \\
\text { C1, or similar certificate) } \\
\text { Cambridge CAE grade A, CPE grade A, B or C / Trinity } 12 \\
\text { (CEFR C2, a similar certificate, or native speaker) }\end{array}$ \\
\hline $\begin{array}{l}\text { 16. Can you do the following? } \\
\text { Answer using } 1 \text { (No) to } 5 \text { (Yes) to } \\
\text { express how confident you feel in } \\
\text { each of these skills. }\end{array}$ & $\begin{array}{l}\text { - I can understand in detail texts within my field of interest or } \\
\text { the area of my academic or professional speciality. [B2.2] } \\
\text { I can understand the motives behind the characters' actions } \\
\text { and their consequences for the development of the plot in a } \\
\text { narrative or play. [B2.2] } \\
\text { - I can rapidly grasp the content and the significance of news, }\end{array}$ \\
\hline
\end{tabular}


17. Can you do the following? Answer using 1 (No) to 5 (Yes) to express how confident you feel in each of these skills.
18. Can you do the following? Answer using 1 (No) to 5 (Yes) to express how confident you feel in each of these skills. articles and reports on topics connected with my interests or my job, and decide if a closer reading is worthwhile. [B2.1]

- I can read and understand articles and reports on current problems in which the writers' express specific attitudes and points of view (e.g. arts reviews, political commentary). [B2.1]

- I can take a quick look through simple, factual texts in magazines, brochures or on a website, and identify whether they contain information that might be of practical use to me. [B1.2]

- I can identify the main conclusions in clearly written texts which argue a point of view. [B1.2]

- I can follow clear, written instructions (for example for a game, the use of a cosmetic or medicine or when using a piece of electronic equipment for the first time). [B1.1]

- I can find out and pass on straightforward factual information. [B1.1]

- I can use a variety of linking words efficiently to mark the relationships between ideas clearly. [B2.2]

- I can develop an argument systematically in a composition or report, emphasising decisive points and including supporting details. [B2.2]

- I can present a topical issue in a critical manner and weigh up the advantages and disadvantages of various options. [B2.1]

- I can write clear, detailed descriptions on a variety of subjects related to my field of interest. [B2.1]

- I can communicate with reasonable accuracy and can correct mistakes if they have led to misunderstandings. [B2.1]

- I can summarise non-routine information on familiar subjects from various sources and present it to others with some confidence. [B1.2]

- I can develop an argument in writing well enough to be followed without difficulty most of the time. [B1.2]

- I can write short, comprehensible connected texts on familiar subjects. [B1.1]

- I can identify speaker viewpoints and attitudes as well as the information content in recordings on social, professional or academic subjects. [B2.2]

- I can understand the main ideas of complex speech delivered in a standard dialect, including technical discussions in my field of specialisation. [B2.1]

- I can understand in detail what is said to me in standard spoken language even in a noisy environment. [B2.1]

- I can follow the essentials of lectures, talks and reports and other forms of academic or professional presentation in my field. [B2.1]

- I can understand announcements and messages on concrete and abstract topics spoken in standard dialect at normal speed. [B2.1]

- I can understand straightforward information about everyday, study- or work-related topics, identifying both general messages and specific details, provided people speak clearly in a familiar accent. [B1.2]

- I can follow a lecture or talk within my own field, provided the subject matter is familiar and the presentation straightforward and clearly structured. [B1.2] 


\begin{tabular}{|c|c|}
\hline & $\begin{array}{l}\text { I can understand the information in audio material on topics } \\
\text { that interest me provided it is spoken clearly in a standard } \\
\text { accent. [B1.2] } \\
\text { I can follow a lot of what is said around me, when people } \\
\text { speak clearly and without using idioms and special } \\
\text { expressions. [B1.2] } \\
\text { I can understand the main points of clear standard speech on } \\
\text { familiar, everyday subjects, provided there is an opportunity } \\
\text { to get repetition or clarification sometimes. [B1.1] }\end{array}$ \\
\hline $\begin{array}{l}\text { 19. Can you do the following? } \\
\text { Answer using } 1 \text { (No) to } 5 \text { (Yes) to } \\
\text { express how confident you feel in } \\
\text { each of these skills. }\end{array}$ & 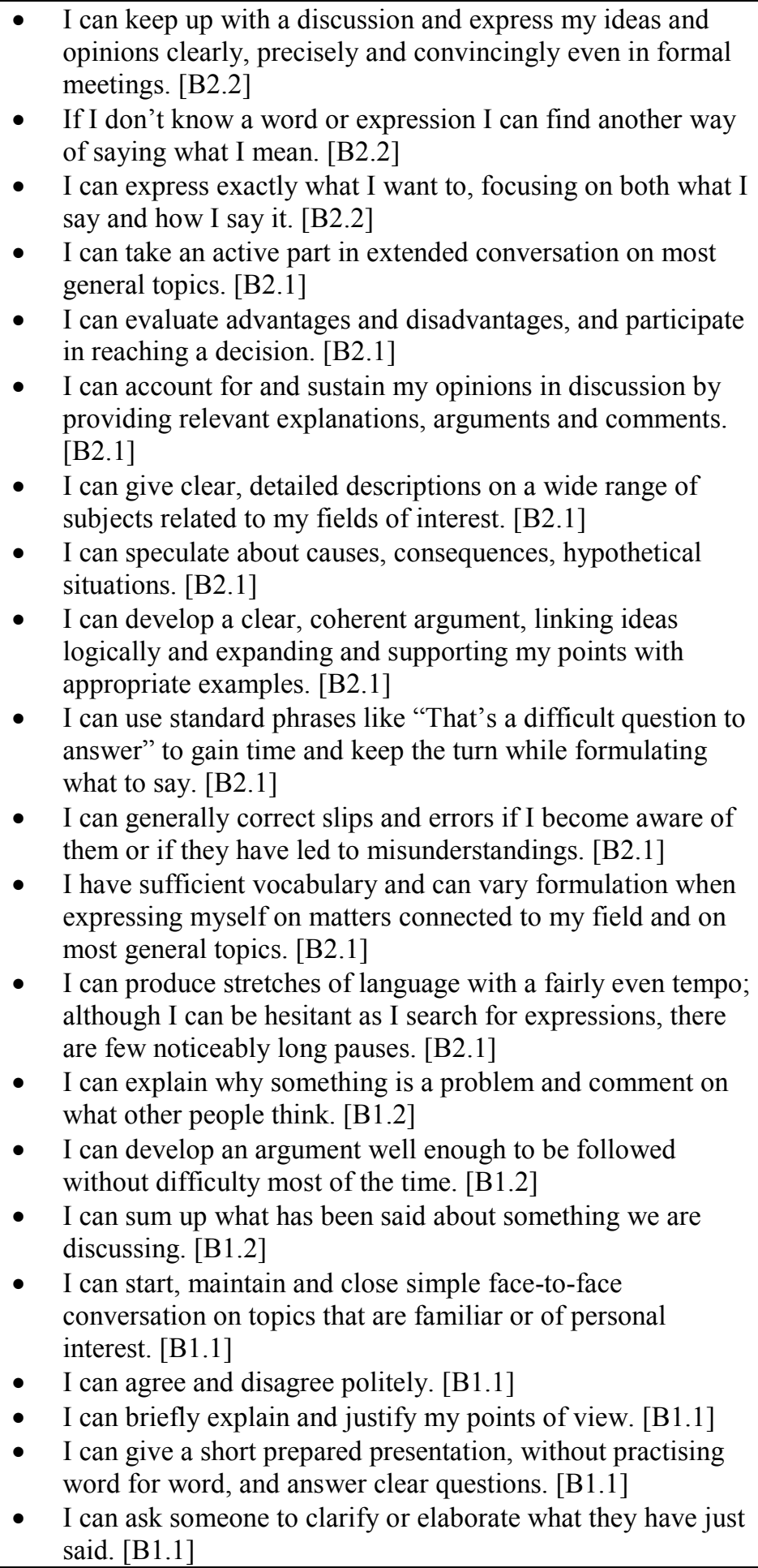 \\
\hline
\end{tabular}


20. Select the statement which best represents your general ability in reading English.

- I can understand any kind of text, including those written in a very colloquial style and containing many idiomatic expressions or slang. [C2]

- I can understand in detail lengthy, complex texts, whether or not they relate to my area of speciality. [C1.2]

- I can understand in detail a wide range of lengthy, complex texts likely to be encountered in social, professional or academic life, though I may want time to reread them. [C1.1]

- I have a broad active reading vocabulary, which means I can read with a large degree of independence, adapting style and speed of reading to different texts and purposes. [B2.2]

- I can read with a large degree of independence, using dictionaries and other reference sources selectively when necessary. [B2.1]

- I can understand the main points in straightforward texts on subjects of personal or professional interest. [B1.2]

- I can understand the main points in straightforward factual texts on subjects of personal or professional interest well enough to talk about them afterwards. [B1.1]

- I can understand short, simple texts on familiar subjects, which consist of high-frequency, everyday or job-related language. [A2.2]

- I can understand short, simple texts containing familiar vocabulary including international words. [A2.1]

- I can read very short, simple texts very slowly by understanding familiar names, words and basic phrases. [A1.2]

- I can recognise names, words and phrases I know and use them to understand very simple sentences if there are pictures. [A1.1]

21. Select the statement which best represents your general ability when writing in English.
- I can produce written work that shows good organisational structure, with an understanding of the style and content appropriate to the task. I can produce text which is proof-read and laid out in accordance with relevant conventions. [C2]

- I can write well-structured texts which show a high degree of grammatical correctness and vary my vocabulary and style according to the addressee, the kind of text and the topic. [C1.2]

- I can write clear, well-structured texts on complex topics in an appropriate style with good grammatical control. [C1.1]

- I can use a range of language to express abstract ideas as well as topical subjects, correcting most of my mistakes in the process. [B2.2]

- I can write at length about topical issues, even though complex concepts may be oversimplified, and can correct many of my mistakes in the process. [B2.1]

- I can write about a variety of familiar subjects well enough for others to follow my story or argument. [B1.2]

- I can write short, comprehensible connected texts on familiar subjects. [B1.1]

- I can write about my everyday life in simple sentences (people, places, job, school, family, hobbies, etc.). [A2.2]

- I can write about myself using simple language. For example: information about my family, school, job, hobbies, etc.

[A2.1]

- I can write simple sentences about myself, for example, 


\begin{tabular}{|c|c|}
\hline & $\begin{array}{l}\text { where I live and what I do. [A1.2] } \\
\text { I can write about myself and where I live, using short, simple } \\
\text { phrases. [A1.1] }\end{array}$ \\
\hline $\begin{array}{l}\text { 22. Select the statement which best } \\
\text { represents your general ability to } \\
\text { understand spoken in English. }\end{array}$ & $\begin{array}{l}\text { - I can understand any kind of spoken language, whether live } \\
\text { or broadcast, delivered at fast speed, even in a noisy } \\
\text { environment. I can appreciate irony and sarcasm and draw } \\
\text { appropriate conclusions about their use. [C2] } \\
\text { I can understand a wide range of idiomatic expressions and } \\
\text { colloquialisms, appreciating shifts in style and register. } \\
\text { [C1.2] } \\
\text { I can understand enough to follow extended speech on } \\
\text { abstract and complex topics of academic or vocational } \\
\text { relevance. [C1.1] } \\
\text { - I can understand standard spoken language, live or broadcast, } \\
\text { even in a noisy environment. [B2.2] } \\
\text { I can understand the main ideas of complex speech on } \\
\text { concrete and abstract topics delivered in a standard dialect, } \\
\text { including technical discussions in my field of specialisation. } \\
\text { [B2.1] } \\
\text { I can understand straightforward information about everyday, } \\
\text { study- or work-related topics, identifying both general } \\
\text { messages and specific details, provided people speak clearly } \\
\text { in a familiar accent. [B1.2] } \\
\text { I can understand the main points of clear standard speech on } \\
\text { familiar, everyday subjects, provided there is an opportunity } \\
\text { to get repetition or clarification sometimes. [B1.1] } \\
\text { I can understand enough of what people say to be able to } \\
\text { meet immediate needs, provided people speak slowly and } \\
\text { clearly. [A2.2] } \\
\text { I can understand simple information and questions about } \\
\text { family, people, homes, work and hobbies. [A2.1] } \\
\text { I can understand people if they speak very slowly and clearly } \\
\text { about simple everyday topics. I can understand people } \\
\text { describing objects and possessions (e.g. colour and size). } \\
\text { [A1.2] } \\
\text { I can understand simple words and phrases, like "excuse me", } \\
\text { "sorry", "thank you", etc. I can understand the days of the } \\
\text { week and months of the year. I can understand times and } \\
\text { dates. I can understand numbers and prices. [A1.1] }\end{array}$ \\
\hline $\begin{array}{l}\text { 23. Which of these is closest to } \\
\text { what you can do when } \\
\text { understanding spoken English? }\end{array}$ & $\begin{array}{l}\text { - I can recognise familiar words and very basic phrases } \\
\text { concerning myself, my family and immediate concrete } \\
\text { surroundings when people speak slowly and clearly. [A1] } \\
\text { I can understand phrases and the highest frequency } \\
\text { vocabulary related to areas of most immediate personal } \\
\text { relevance (e.g. very basic personal and family information, } \\
\text { shopping, local area, employment). I can catch the main point } \\
\text { in short, clear, simple messages and announcements. [A2] } \\
\text { I can understand the main points of clear standard speech on } \\
\text { familiar matters regularly encountered in work, school, } \\
\text { leisure, etc. I can understand the main point of many radio or } \\
\text { TV programmes on current affairs or topics of personal or } \\
\text { professional interest when the delivery is relatively slow and } \\
\text { clear. [B1] } \\
\text { I can understand extended speech and lectures and follow } \\
\text { even complex lines of argument provided the topic is } \\
\text { reasonably familiar. I can understand most TV news and } \\
\text { current affairs programmes. I can understand the majority of }\end{array}$ \\
\hline
\end{tabular}




\begin{tabular}{|c|c|}
\hline & $\begin{array}{l}\text { films in standard dialect. [B2] } \\
\text { - I can understand extended speech even when it is not clearly } \\
\text { structured and when relationships are only implied and not } \\
\text { signalled explicitly. I can understand television programmes } \\
\text { and films without too much effort. [C1] } \\
\text { I have no difficulty in understanding any kind of spoken } \\
\text { language, whether live or broadcast, even when delivered at } \\
\text { fast native speed, provided I have some time to get familiar } \\
\text { with the accent. [C2] }\end{array}$ \\
\hline $\begin{array}{l}24 . \text { Which of these is closest to } \\
\text { what you can do when } \\
\text { understanding texts in English? }\end{array}$ & $\begin{array}{l}\text { - I can understand familiar names, words and very simple } \\
\text { sentences, for example on notices and posters or in } \\
\text { catalogues. [A1] } \\
\text { I can read very short, simple texts. I can find specific, } \\
\text { predictable information in simple everyday material such as } \\
\text { advertisements, prospectuses, menus and timetables, and I } \\
\text { can understand short simple personal letters. [A2] } \\
\text { I can understand texts that consist mainly of high frequency } \\
\text { everyday or job-related language. I can understand the } \\
\text { description of events, feelings and wishes in personal letters. } \\
\text { [B1] } \\
\text { I can read articles and reports concerned with contemporary } \\
\text { problems in which the writers adopt particular attitudes or } \\
\text { viewpoints. I can understand contemporary literary prose. } \\
\text { [B2] } \\
\text { I can understand long and complex factual and literary texts, } \\
\text { appreciating distinctions of style. I can understand specialised } \\
\text { articles and longer technical instructions, even when they do } \\
\text { not relate to my field. [C1] } \\
\text { I can read with ease virtually all forms of the written } \\
\text { language, including abstract, structurally or linguistically } \\
\text { complex texts such as manuals, specialised articles and } \\
\text { literary works. [C2] }\end{array}$ \\
\hline $\begin{array}{l}25 . \text { Which of these is closest to } \\
\text { what you can do when talking to } \\
\text { others in English? }\end{array}$ & $\begin{array}{l}\text { - I can interact in a simple way provided the other person is } \\
\text { prepared to repeat or rephrase things at a slower rate of } \\
\text { speech and help me formulate what I'm trying to say. I can } \\
\text { ask and answer simple questions in areas of immediate need } \\
\text { or on very familiar topics. [A1] } \\
\text { I can communicate in simple and routine tasks requiring a } \\
\text { simple and direct exchange of information on familiar topics } \\
\text { and activities. I can handle very short social exchanges, even } \\
\text { though I can't usually understand enough to keep the } \\
\text { conversation going myself. [A2] } \\
\text { I can deal with most situations likely to arise whilst travelling } \\
\text { in an area where the language is spoken. I can enter } \\
\text { unprepared into conversation on topics that are familiar, of } \\
\text { personal interest or pertinent to everyday life (e.g. family, } \\
\text { hobbies, work, travel and current events). [B1] } \\
\text { I can interact with a degree of fluency and spontaneity that } \\
\text { makes regular interaction with native speakers quite possible. } \\
\text { I can take an active part in discussion in familiar contexts, } \\
\text { accounting for and sustaining my views. [B2] } \\
\text { I can express myself fluently and spontaneously without } \\
\text { much obvious searching for expressions. I can use language } \\
\text { flexibly and effectively for social and professional purposes. I } \\
\text { can formulate ideas and opinions with precision and relate } \\
\text { my contribution skilfully to those of other speakers. [C1] } \\
\text { I can take part effortlessly in any conversation or discussion }\end{array}$ \\
\hline
\end{tabular}




\begin{tabular}{|c|c|}
\hline & $\begin{array}{l}\text { and have a good familiarity with idiomatic expressions and } \\
\text { colloquialisms. I can express myself fluently and convey } \\
\text { finer shades of meaning precisely. If I do have a problem, I } \\
\text { can backtrack and restructure around the difficulty so } \\
\text { smoothly that other people are hardly aware of it. [C2] }\end{array}$ \\
\hline $\begin{array}{l}\text { 26. Which of these is closest to } \\
\text { what you can do when speaking on } \\
\text { your own in English? }\end{array}$ & $\begin{array}{l}\text { - I can use simple phrases and sentences to describe where I } \\
\text { live and people I know. [A1] } \\
\text { I can use a series of phrases and sentences to describe in } \\
\text { simple terms my family and other people, living conditions, } \\
\text { my educational background and my present or most recent } \\
\text { job. [A2] } \\
\text { I can connect phrases in a simple way in order to describe } \\
\text { experiences and events, my dreams, hopes and ambitions. I } \\
\text { can briefly give reasons and explanations for opinions and } \\
\text { plans. I can narrate a story or relate the plot of a book or film } \\
\text { and describe my reactions. [B1] } \\
\text { I can present clear, detailed descriptions on a wide range of } \\
\text { subjects related to my field of interest. I can explain a } \\
\text { viewpoint on a topical issue giving the advantages and } \\
\text { disadvantages of various options. [B2] } \\
\text { I can present clear, detailed descriptions of complex subjects } \\
\text { integrating sub-themes, developing particular points and } \\
\text { rounding off with an appropriate conclusion. [C1] } \\
\text { I can present a clear, smoothly-flowing description or } \\
\text { argument in a style appropriate to the context and with an } \\
\text { effective logical structure which helps the recipient to notice } \\
\text { and remember significant points. [C2] }\end{array}$ \\
\hline $\begin{array}{l}\text { 27. Which of these is closest to } \\
\text { what you can do when writing in } \\
\text { English? }\end{array}$ & $\begin{array}{l}\text { - I can write a short, simple postcard, for example, sending } \\
\text { holiday greetings. I can fill in forms with personal details, for } \\
\text { example entering my name, nationality and address on a hotel } \\
\text { registration form. [A1] } \\
\text { - I can write short, simple notes and messages relating to } \\
\text { matters in areas of immediate needs. I can write a very simple } \\
\text { personal letter, for example thanking someone for something. } \\
\text { [A2] } \\
\text { I can write simple connected text on topics which are familiar } \\
\text { or of personal interest. I can write personal letters describing } \\
\text { experiences and impressions. [B1] } \\
\text { I can write clear, detailed text on a wide range of subjects } \\
\text { related to my interests. I can write an essay or report, passing } \\
\text { on information or giving reasons in support of or against a } \\
\text { particular point of view. I can write letters highlighting the } \\
\text { personal significance of events and experiences. [B2] } \\
\text { I can express myself in clear, well-structured text, expressing } \\
\text { points of view at some length. I can write about complex } \\
\text { subjects in a letter, an essay or a report, underlining what I } \\
\text { consider to be the salient issues. I can select style appropriate } \\
\text { to the reader in mind. [C1] } \\
\text { I can write clear, smoothly-flowing text in an appropriate } \\
\text { style. I can write complex letters, reports or articles which } \\
\text { present a case with an effective logical structure which helps } \\
\text { the recipient to notice and remember significant points. I can } \\
\text { write summaries and reviews of professional or literary } \\
\text { works. [C2] }\end{array}$ \\
\hline
\end{tabular}




\section{III.2.2 Final survey}

This survey builds heavily upon the initial questionnaire. For this reason, items 31-42, being identical to $16-27$, are not reproduced here.

Table 2. English Level Self-Assessment: Final Survey.

\begin{tabular}{|c|c|}
\hline $\begin{array}{l}\text { 28. After receiving lectures and } \\
\text { performing tasks in another } \\
\text { language, how has your English } \\
\text { level changed? What skills have } \\
\text { you improved the most? } \\
\text { Write a short comment about your } \\
\text { ideas. }\end{array}$ & (Open answer) \\
\hline $\begin{array}{l}\text { 29. How much do you consider you } \\
\text { have improved your language skills } \\
\text { after the module? } 1=\text { not at all; } 5=\mathrm{I} \\
\text { have improved a lot }\end{array}$ & $\begin{array}{ll}\text { - } & \text { Grammar structures (1-5) } \\
\text { - } & \text { Vocabulary (1-5) } \\
\text { - } & \text { Understanciation (1-5) } \\
\text { - } & \text { Understanding what I read (1-5) } \\
\text { - } & \text { Understanding other foreakers (1-5) } \\
& (1-5) \\
\text { - } & \text { Writing long, formal texts }(1-5) \\
- & \text { Writing short, informal texts (1-5) } \\
\text { - } & \text { Speaking English with native speakers }(1-5) \\
\text { - } & \text { Speaking English with other foreigners }(1-5) \\
\end{array}$ \\
\hline $\begin{array}{l}\text { 30. How would you describe your } \\
\text { general level of English at present? }\end{array}$ & $\begin{array}{ll}\text { - } & \text { Basic or Elementary } \\
\text { - } & \text { Pre-intermediate } \\
\text { - } & \text { Untermediate } \\
\text { - } & \text { Advancer-intermediate } \\
\text { - } & \text { Proficient / Bilingual } \\
\end{array}$ \\
\hline
\end{tabular}

\section{III.3. Data evaluation}

Finally, in the evaluation stage, quantitative data from these channels above are collated and analysed in order to trace the impact of EMI on students' self-perceived evolution. When analysing data following our method, two strategies are observed: control and scoring. Student data are controlled by three groups of items per skill, so that their level is not severely influenced by a single choice. Student responses are weighted and, using a software package for statistical analysis, greater variance in student choices for descriptors at the same level is deleveraged. Student responses are scored and distributed across the CEFR levels as follows: 
Table 3. CEFR level default scores.

\begin{tabular}{|c|c|}
\hline Level & Default Score \\
\hline C2 & 100 \\
\hline C1.2 & 90 \\
\hline C1.1 & 80 \\
\hline B2.2 & 70 \\
\hline B2.1 & 60 \\
\hline B1.2 & 50 \\
\hline B1.1 & 40 \\
\hline A2.2 & 30 \\
\hline A2.1 & 20 \\
\hline A1.2 & 10 \\
\hline A1.1 & 5 \\
\hline
\end{tabular}

Items which show module-specific sub-skills (16-19) are analysed in a specific way: for each item, each of the self-assessed options (1-5) is multiplied by its default level score shown in Table 3 and the mean of the multiple choice values is adjusted to the value of the maximum potential score ( 5 x 100 C2 level score). Choices in items 20-27 are given the value of the default score for their level. The total for the skill is calculated using the weighted mean of the values in each category, unless adjusted by the statistical software, and interpreted as the level for that particular skill as referred to above. As an indication, we calculate the global level of the student as the mean of the four skills.

Table 4. Outline of the analysis scoring.

\begin{tabular}{|c|c|c|c|}
\hline Skill & $\begin{array}{c}\text { Item } \\
\text { (weight) }\end{array}$ & Score & Total \\
\hline \multirow{3}{*}{ Reading } & $16(50 \%)$ & $\begin{array}{l}\text { Adjusted mean (choice } 1 \times \text { level score, choice } 2 \times \text { level } \\
\text { score, choice } 3 \times \text { level score ...) }\end{array}$ & \multirow{3}{*}{ Weighted mean } \\
\hline & $20(25 \%)$ & Choice $\mathrm{x}$ level score & \\
\hline & $24(25 \%)$ & Choice $\mathrm{x}$ level score & \\
\hline \multirow{3}{*}{ Writing } & $17(50 \%)$ & $\begin{array}{l}\text { Adjusted mean (choice } 1 \times \text { level score, choice } 2 \times \text { level } \\
\text { score , choice } 3 \times \text { level score ...) }\end{array}$ & \multirow{3}{*}{ Weighted mean } \\
\hline & $21(25 \%)$ & Choice $\mathrm{x}$ level score & \\
\hline & $27(25 \%)$ & Choice $\mathrm{x}$ level score & \\
\hline \multirow{3}{*}{ Listening } & $18(50 \%)$ & $\begin{array}{l}\text { Adjusted mean (choice } 1 \times \text { level score, choice } 2 \times \text { level } \\
\text { score , choice } 3 \times \text { level score ...) }\end{array}$ & \multirow{3}{*}{ Weighted mean } \\
\hline & $22(25 \%)$ & Choice $\mathrm{x}$ level score & \\
\hline & $23(25 \%)$ & Choice $\mathrm{x}$ level score & \\
\hline \multirow{3}{*}{ Speaking } & $19(50 \%)$ & $\begin{array}{l}\text { Adjusted mean (choice } 1 \times \text { level score, choice } 2 \times \text { level } \\
\text { score , choice } 3 \times \text { level score ...) }\end{array}$ & \multirow{3}{*}{ Weighted mean } \\
\hline & $25(25 \%)$ & Choice $\mathrm{x}$ level score & \\
\hline & $26(25 \%)$ & Choice x level score & \\
\hline Overall & \multicolumn{2}{|r|}{ Only as an indication of student's overall level } & Mean \\
\hline
\end{tabular}




\section{III.3.1 Sample analysis}

The sample below is from Julia A., a first-year 19-year-old female student in an Economics degree programme at a state-funded Spanish University. Her L1 is Spanish, with 12 years of English instruction. Julia finds pronunciation and speaking to foreigners particularly difficult, and thinks that writing is her strongest skill. She regularly reads webpages and forums in English, but she does not often listen to or speak English. Julia has been to an English-speaking country for less than three months altogether, and she shows a positive attitude towards the English language and cultures. She has received extra-curricular English lessons for about two years, and she has not obtained any kind of language certificate. Julia describes her level of English as intermediate, and expects to use English in the future to improve her employability.

Table 5. Initial survey (24 Sept 2012).

\begin{tabular}{|c|c|c|c|}
\hline Skill & Item & Score & Total \\
\hline \multirow[t]{2}{*}{ Reading } & 16 & $\begin{array}{l}\text { Option 1, B2.2: } 4 \text { × 70 }=280 \\
\text { Option 2, B2.2: } 3 \text { × } 70=210 \\
\text { Option 3, B2.1: } 5 \text { × } 60=300 \\
\ldots \\
\text { Mean: } 263.8 \quad \text { Adjusted mean: } 26380 / 500=52.8\end{array}$ & \multirow[t]{2}{*}{$58.9[\mathrm{~B} 1.2]$} \\
\hline & $\frac{20}{24}$ & $\begin{array}{l}\text { Option 5, B2.1: } 60 \\
\text { Option 4, B2.2: } 70\end{array}$ & \\
\hline \multirow[t]{2}{*}{ Writing } & 17 & $\begin{array}{l}\text { Option 1, B2.2: } 4 \text { × } 70=280 \\
\text { Option 2, B2.2: } 4 \text { × } 70=280 \\
\text { Option 3, B2.1: } 5 \text { × } 60=300 \\
\ldots \\
\text { Mean: } 272.3 \quad \text { Adjusted mean: } 27230 / 500=54.5\end{array}$ & \multirow[t]{2}{*}{$64.8[\mathrm{~B} 2.1]$} \\
\hline & $\begin{array}{ll}21 \\
27\end{array}$ & $\begin{array}{l}\text { Option 3, C1.1: } 80 \\
\text { Option 4, B2.2: } 70\end{array}$ & \\
\hline \multirow[t]{3}{*}{ Listening } & 18 & $\begin{array}{l}\text { Option 1, B2.2: } 3 \times 70=210 \\
\text { Option 2, B2.1: } 4 \text { × } 60=240 \\
\text { Option 3, B2.1: } 5 \text { × } 60=300 \\
\ldots \\
\text { Mean: } 245.8 \quad \text { Adjusted mean: } 24580 / 500=49.2\end{array}$ & \multirow[t]{3}{*}{49.6 [B1.1] } \\
\hline & 22 & Option 6, B1.2: 50 & \\
\hline & 23 & Option 6, B1.2: 50 & \\
\hline \multirow[t]{2}{*}{ Speaking } & 19 & $\begin{array}{l}\text { Option 1, B2.2: } 3 \times 70=210 \\
\text { Option 2, B2.2: } 4 \text { × } 70=280 \\
\text { Option 3, B2.2: } 3 \text { × } 60=180 \\
\ldots \\
\text { Mean: } 196.8 \quad \text { Adjusted mean: } 19680 / 500=39,4\end{array}$ & \multirow[t]{2}{*}{$44.7[\mathrm{~B} 1.1]$} \\
\hline & $\frac{25}{26}$ & $\begin{array}{l}\text { Option 3, B1.2: } 50 \\
\text { Option 3, B1.2: } 50\end{array}$ & \\
\hline Overall & & Only as an indication of student global level & $54.5[\mathrm{~B} 1.2]$ \\
\hline
\end{tabular}


Table 6. Final survey (12 July 2013).

\begin{tabular}{|c|c|c|c|}
\hline Skill & Item & Score & Total \\
\hline \multirow[t]{3}{*}{ Reading } & 16 & $\begin{array}{l}\text { Option 1, B2.2: } 4 \text { × } 70=280 \\
\text { Option 2, B2.2: } 4 \text { × } 70=280 \\
\text { Option 3, B2.1: } 5 \text { x } 60=300 \\
\ldots \quad \text { Adjusted mean: } 28320 / 500=56.6 \\
\text { Mean: } 283.2 \quad \text { Ad }\end{array}$ & \multirow[t]{3}{*}{$63.3[\mathrm{~B} 2.1]$} \\
\hline & 20 & Option 4, B2.2: 70 & \\
\hline & 24 & Option 4, B2.2: 70 & \\
\hline \multirow[t]{3}{*}{ Writing } & 17 & $\begin{array}{l}\text { Option 1, B2.2: } 5 \text { × } 70=350 \\
\text { Option 2, B2.2: } 4 \text { x } 70=280 \\
\text { Option 3, B2.1: } 5 \text { x } 60=300 \\
\ldots \quad \text { Adjusted mean: } 29870 / 500=59.7 \\
\text { Mean: } 298.7 \quad \text { Ad }\end{array}$ & \multirow[t]{3}{*}{$69.9[\mathrm{~B} 2.2]$} \\
\hline & 21 & Option 3, C1.1: 80 & \\
\hline & 27 & Option 4, B1.1: 80 & \\
\hline \multirow[t]{3}{*}{ Listening } & 18 & $\begin{array}{l}\text { Option 1, B2.2: } 4 \text { x } 70=280 \\
\text { Option 2, B2.1: } 4 \text { x } 60=240 \\
\text { Option 3, B2.1: } 5 \text { x } 60=300 \\
\ldots \quad \text { Adjusted mean: } 26620 / 500=53.2 \\
\text { Mean: } 266.2 \quad \text { A }\end{array}$ & \multirow[t]{3}{*}{$61.6[\mathrm{~B} 2.1]$} \\
\hline & 22 & Option 4, B2.2: 70 & \\
\hline & 23 & Option 6, B2.2: 70 & \\
\hline \multirow[t]{3}{*}{ Speaking } & 19 & $\begin{array}{l}\text { Option 1, B2.2: } 4 \text { × } 70=280 \\
\text { Option 2, B2.2: } 5 \text { x } 70=350 \\
\text { Option 3, B2.2: } 4 \text { x } 60=240 \\
\ldots \quad \text { Adjusted mean: } 23120 / 500=46.2 \\
\text { Mean: } 231.2 \quad\end{array}$ & \multirow[t]{3}{*}{$53.1[\mathrm{~B} 1.2]$} \\
\hline & 25 & Option 4, B2.1: 60 & \\
\hline & 26 & Option 4, B2.1: 60 & \\
\hline Overall & & Only as an indication of student global level & $62[\mathrm{~B} 2.1]$ \\
\hline
\end{tabular}

Table 6. Skills variance (from 24 September 2012 to 12 July 2013)

\begin{tabular}{|c|c|c|c|c|}
\hline Skill & Initial & Final & Variance & Level Variance \\
\hline Reading & $58.9[\mathrm{~B} 1.2]$ & $63.3[\mathrm{~B} 2.1]$ & +4.4 & +0.5 \\
\hline Writing & $64.8[\mathrm{~B} 2.1]$ & $69.9[\mathrm{~B} 2.2]$ & +5.1 & +1 \\
\hline Listening & $49.6[\mathrm{~B} 1.1]$ & $61.6[\mathrm{~B} 2.1]$ & +12 & +0.5 \\
\hline Speaking & $44.7[\mathrm{~B} 1.1]$ & $53.1[\mathrm{~B} 1.2]$ & +8.4 & +0.5 \\
\hline Overall & $54.5[\mathrm{~B} 1.2]$ & $62[\mathrm{~B} 2.1]$ & +7.5 & +12 \\
\hline
\end{tabular}




\section{PROVIDING EVIDENCE: FURTHER STEPS}

For the particular case of Julia, her self-assessment reveals a significant improvement in all skills despite receiving no language lessons. Before readily attributing that improvement to EMI, further and deeper work needs to be carried out to assess the objective extent of that influence and its social triggers (Llinares and Morton 2012). Here, we have contrasted this possible influence of EMI against three recorded taskbased observations to evaluate student performance by analysing discourse and written work. Some variation was found between their own self-assessment and their actual performance in many of the sub-skills included in the questionnaire (HernandezNanclares and Jimenez-Munoz 2014). The objective assessment we present here would need to be performed on a substantial cohort at a number of institutions over a period of time to give further evidence supporting the CLIL hypotheses. The research method we present here is flexible and subject to refinement and adaptation for that purpose. It could contribute to the considerably small amount of quantitative research conducted on the impact of language-based interventions on language competence and academic performance within CLIL contexts. Furthermore, modelling of student profiles would enable preventive interventions to be designed. Such interventions are particularly well suited to the context of plurilingual higher education, where it is essential to attest the quality of teaching and learning, and to ascertain cross-disciplinary best practices.

\section{REFERENCES}

Aguilar, M. and Muñoz, C. 2013. "The effect of proficiency on CLIL benefits in engineering students in Spain". International Journal of Applied Linguistics, forthcoming. 1 March 2014 $<$ http://onlinelibrary.wiley.com/doi/10.1111/ijal.12006/pdfs

Airey, J. 2012. “'I don't teach language'. The linguistic attitudes of physics lecturers in Sweden”. In Smit, U. and E. Dafouz (Eds.) Integrating Content and Language in Higher Education. Gaining Insights into English-Medium Instruction at European Universities. Special Issue of AILA Review 25, 64-79.

Alexander, J. R. 2006. "International programmes in the German-speaking world and englishization: a critical analysis". In Wilkinson, R. and Zegers, V. (Eds.) 
Realizing Content and Language Integration in Higher Education. Maastricht: Universitaire Pers, 77-95.

Ball, P. and Lindsay, D. 2013. "Language demands and support for English-medium instruction in tertiary education: learning from a specific context”. In Doiz, A., D. Lasagabaster and J.M. Sierra (Eds.) English-medium instruction at universities: global challenges. Bristol: Multilingual Matters, 44-64.

Barnett, W. S. Yarosz, D. J. Thomas, J. Jung, K. and Blanco, D. (2007). “Two-way and monolingual English immersion in preschool education: an experimental comparison”. Early Childhood Research Quarterly 22, 227-293.

Bonnet, A. 2012. "Towards an evidence base for CLIL: how to integrate qualitative and quantitative as well as process, product and participant perspectives in CLIL research". International CLIL Research Journal 1 (4), 65-78.

Clegg, J. 2001. "Can English-medium education work? Why we should be honest about its failures and courageous about change”. In Trewby R. and S. Fitchat (Eds.) Language and Development in Southern Africa. Windhoek: Macmillan, 210-226.

Cobb, B., Vega, D., and Kronauge, C. 2009. "Effects of an elementary dual language immersion school program on junior high school achievement" In Hough, D. L. (Ed.) Middle grades research: Exemplary studies linking theory to practice. Charlotte, NC: Information Age Publishing, 27-47.

Coleman, J. 2006. "English-medium teaching in European higher education". Language Teaching 39 (1), 1-14.

Costa, F. and Coleman, J. A. 2010. "Integrating Content and Language in higher education in Italy: ongoing research'. International CLIL Research Journal 1 (3), 19-29.

Coyle, D. 2008. "CLIL - a pedagogical approach from the European perspective”. In Van Deusen-scholl, N. and N. Hornberger (Eds.) Encyclopaedia of Language and Education 2nd Edition Vol. 4. New York: Springer, 1200-1214.

Coyle, D. Hood, P. and Marsh, D. 2010. CLIL: Content and Language Integrated Learning. Cambridge: Cambridge University Press.

Erling, E. and Hilgendorf, S. 2006. "Language policies in the context of German higher education". Language Policy 5, 267-292.

Fortanet-Gómez, I. 2013. CLIL in Higher Education. Towards a Multilingual 
Language Policy. Bristol: Multilingual Matters.

Hernandez-Nanclares, N. and Jimenez-Munoz, A. 2014. "English as a Medium of Instruction: research project in bilingual economic education”. International Review of Economics Education 15, in print.

Hunter, M. and Parchoma, P. 2012. "Content and Language Integrated Learning: shifting boundaries and terrain mapping”. In Hodgson, V., C. Jones, M. de Laat, D. McConnell, T. Ryberg and P. Sloep (Eds.) Proceedings of the eighth International Conference on Networked Learning, 2-4 April, 2012. Maastricht: Maastricht School of Management, 514-521.

Kirkgöz, Y. 2005. "Motivation and student perception of studying in an Englishmedium university". Journal of Language and Linguistic Studies 1 (1), 101-123.

Kirkgöz, Y. 2009. "Students' and lecturers' perceptions of the effectiveness of foreign language instruction in an English-medium university in Turkey". Teaching in Higher Education 14 (1), 81-93.

Lasagabaster D. and Sierra, J. M. 2010. "Immersion and CLIL in English: more differences than similarities". ELT Journal 64, 376-395.

Lindholm-Leary, K. J. 2011. “Achievement and language proficiency of Latino students in dual language programmes: native English speakers, fluent English/previous ELLs, and current ELLs". Journal of Multilingual \& Multicultural Development 32(6), 531-545.

Llinares, A. and Whittaker, R. 2010. "Writing and speaking in the history class: data from CLIL and first language contexts". In Dalton-Puffer, C., T. Nikula, \& U. Smit (Eds.) Language use and language learning in CLIL classrooms. Amsterdam: John Benjamins, 125-144.

Llinares, A., and Morton, T. 2012. "Social perspectives on interaction and language learning in CLIL classrooms". In Alcón-Soler, E. and M.P. Safont-Jorda (Eds.) Discourse and learning across L2 instructional contexts. Amsterdam: Rodopi, 105-131.

Llinares, A., Morton, T. and Whittaker, R. 2012. The roles of language in CLIL. Cambridge, UK: Cambridge University Press.

Londo, M. 2012. Optimising EMI in higher education through CLIL: case study at Vienna. Vienna: Lap Lamberg. 
Marsh, D. 2002. CLIL/EMILE, The European Dimension: Actions, Trends and Foresight Potential. Jyväskylä: University of Jyväskylä.

Marsh, D. 2006. "English as a medium of instruction in the new global linguistic order: Global characteristics, Local Consequences". In Stewart, S., Olearski, J and D. Thompson (Eds.). Proceedings of the Second Annual Conference for Middle East Teachers of Science, Mathematics and Computing. Abu Dhabi: METSMaC, 2938.

Marsh, D. Mehisto, P. Wolff, D. and Frigols, M. J. 2012. European framework for CLIL teacher education: a framework for the professional development of CLIL teachers. Graz: European Centre for Modern Languages.

Mellion, M. J. 2006. "The Challenge of Changing Tongues in Business University Education". In Wilkinson R. and V. Zegers (Eds). Realizing Content and Language Integration in Higher Education. Maastricht: Universitaire Pers, 212227.

Morrison, J., Merrick, B., Higgs, S., and Le Métais, J. 2005. "Researching the performance of international students in the UK". Studies in Higher Education 30 (3), $327-337$.

Navés, T. 2011. "The promising benefits of integrating content and language for EFL writing and overall EFL proficiency". In Ruiz de Zarobe, Y., J. M. Sierra and F. Gallardo del Puerto (Eds.) Content and Foreign Language Integrated Learning. Contributions to Multilingualism in European Contexts. Bern: Peter Lang, 75103.

Rienties, B. Brouwer, N., and Lygo-Baker, S. 2013. "The effects of online professional development on higher education teachers' beliefs and intentions towards learning facilitation and technology". Teaching and Teacher Education 29, 122-131.

Ruiz de Zarobe, Y. 2010. "Written production and CLIL: An Empirical Study". In Dalton Puffer, C., T. Nikula, and U. Smit (Eds.) Language Use and Language Learning in CLIL classrooms. Philadelphia: John Benjamins, 191-212.

Thomas, W. P. and Collier, V. P. 2002. A national study of school effectiveness for language minority students' long-term academic achievement. Santa Cruz, CA: University of California at Santa Cruz. 
Vizconde, C. J. 2006. "Attitudes of student teachers towards the use of English as language of instruction for science and mathematics in the Philippines". The Linguistics Journal, 1 (3), 7-33.

Received: 13 June 2013

Accepted: 12 March 2014

Cite this article as:

Jiménez-Muñoz, A.J. 2014. "Measuring the impact of CLIL on language skills: a CEFR-based approach for Higher Education". Language Value 6 (1), 28-50. Jaume I University ePress: Castelló, $\quad$ Spain. $\quad \underline{\text { http://www.e-revistes.uji.es/languagevalue. }} \quad$ DOI: http://dx.doi.org/10.6035/LanguageV.2014.6.4

ISSN 1989-7103

Articles are copyrighted by their respective authors 